\title{
LEFT PARTIES, POOR VOTERS, AND ELECTORAL PARTICIPATION IN ADVANCED INDUSTRIAL SOCIETIES
}

\author{
Christopher J. Anderson \\ Department of Government \\ 308 White Hall \\ Cornell University \\ Ithaca, NY 14853 \\ (607) 255-8819 (voice) \\ (607) 255-4530 (fax) \\ christopher.anderson@cornell.edu \\ Pablo Beramendi \\ University of Oxford, University College \\ High Street, Oxford \\ OX14BH, UK \\ +441865276637 (voice) \\ +441865276790 (fax) \\ pablo.beramendi@politics.ox.ac.uk
}

\begin{abstract}
While income inequality is an important normative issue for students of democratic politics, little is known about its effects on citizens' electoral participation. We develop a formal model of the incentives for left parties to mobilize lower income voters. It posits that countries' income distributions and competition on the left provide different incentives for left parties to mobilize lower income voters. In the absence of political competition, higher levels of income inequality reduce the incentives of dominant left parties to target lower income voters. However, competition on the left creates incentives for a dominant left party to mobilize lower income voters, thus counteracting the negative impact of inequality on parties' incentives to target them. As a consequence, the negative association between inequality and turnout at the aggregate level is muted by the presence of several parties on the left side of the political spectrum. Using aggregate data on elections in OECD countries between 1980 and 2002 and election surveys collected in the second wave of the Comparative Study of Electoral Systems project, we find strong and consistent support for our model.
\end{abstract}

\section{Keywords}

industrialized democracies, political parties, Left parties, inequality, voter turnout, electoral politics, mobilization

\section{Word Count}

9,959

Forthcoming in Comparative Political Studies 
The idea that material welfare influences whether and how citizens participate in politics has a long and rich tradition in the social sciences. While scholars have investigated the influence of citizens' material resources or countries' overall economic wellbeing on participation with much vigor, the question of how the distribution of income within society affects civic engagement has received surprisingly little attention from students of comparative politics, ${ }^{1}$ especially in light of debates about rising inequality across some industrialized democracies and the normative importance inequality holds for the quality of democratic life.

Below, we seek to help fill this gap by examining the relationship between income inequality and voter turnout in contemporary democracies. We argue that the distribution of income in society shapes both the incentives of left-wing political parties to mobilize lower income groups as well as the incentives of poorer voters to respond positively to left parties' appeals. Left parties' strategies to mobilize lower income voters will depend on the odds that such mobilizing appeals are successful, while low income voters' responses to the mobilizing efforts of left parties will depend on the credibility of that appeal. Which strategies poor voters and left parties pursue hinges on a country's level of inequality and party competition on the left side of the ideological spectrum. Because left parties expect their efforts to mobilize lower income voters to be less successful in countries with more unequal income distributions, they will spend less effort mobilizing them, and a larger share of low-income voters will become isolated from the political process.

This outcome, however, depends on the absence of a challenger from the left for votes from lower income earners. When a challenger is present, dominant left parties have strong incentives to mobilize low-income voters relative to higher income voters, thus counteracting the negative impact of inequality on incentives to target low income voters. As a consequence, the 
negative association between inequality and turnout is muted when several parties compete on the left. In societies with unequal income distributions but competition on the left, left parties mobilize lower income voters, and these voters are responsive to parties' appeals. As a result, mobilization efforts of lower income voters and turnout are relatively higher in countries with unequal income distributions and multiple left parties.

We proceed as follows. The next section formalizes the argument and develops several testable propositions. We subsequently evaluate these, first, at the aggregate level with the help of instrumental variable regressions of data for national elections across OECD countries between 1980 and 2002; and second, at the level of individual voters with the help of election surveys conducted as part of the Comparative Study of Electoral Systems surveys. We conclude by discussing the limitations and implications of our study and avenues for further research.

\section{Income, Inequality, and Electoral Turnout}

What is the effect of cross-national differences in income inequality on voter turnout? We are aware of only two studies that have investigated this relationship systematically. In one, Goodin and John Dryzek (1980) found that income inequality was negatively correlated with aggregate voter turnout in elections held in the late 1950 s across thirty-eight democracies. ${ }^{2}$ In the other, Solt (2008) concludes on the basis of survey data from 23 democracies in the 1980s and 1990s that income inequality has a negative effect on (reported) voter turnout. These studies are suggestive of a link between inequality and participation, and they offer plausible accounts, centered on the motivations that lower income voters have to participate in elections.

The informal logic underlying existing arguments is based on assumptions about what citizens understand the political consequences of inequality to be (Goodin and Dryzek 1980; Solt 2008). Specifically, it assumes that (relatively) poorer citizens view inequality as favoring the 
policy interests of the (relatively) rich, and that a more unequal distribution of income distorts the representational process in favor of the rich to a greater degree than a more equal distribution would (Dahl 1971; Solt 2008). A more unequal world thus begets apathy among lower income voters (a) because of perceptions of the political system as unresponsive or unrepresentative, and (b) because of a reduced incentive to spend scarce resources on participating when its benefits are less than assured (Goodin and Dryzek 1980).

Voters' beliefs about democratic processes and their incentives to turn out are an important part of the story. We build on this insight and argue that the full story of the link between inequality and turnout consists of the combined product of people's incentives to vote as well as parties' incentives to mobilize specific groups of voters. The starting point for this argument is the idea that the connection between income inequality and turnout is about the effect of relative, rather than absolute, income on the choices parties and voters make. Assuming that parties will try to maximize electoral support by using their redistributive platforms to attract different income groups (Finer, Kenny, and Morton 1993), the distribution of income in society provides political parties with information about the shape of voters' preferences over redistribution and the sizes of different segments of the electorate. Similarly, individual voters' incentives to participate will vary with their own location in the income distribution as well as with the overall shape of that distribution. As a result, and as a starting point for our analysis, we presume that the impact of income on turnout results from the combination of voters' relative position in the income distribution (demand for redistribution) and the expected change in that position associated with different redistributive platforms offered by political parties (supply of redistribution) (cf. Meltzer and Richard 1981). 
This means that an individual's decision to vote and a political party's decision to target a particular subgroup of citizens are interrelated. The probability that a particular individual will vote is in part a function of the expected probability that political parties will effectively represent the individual's interests. However, we believe that this is only part of the story. The missing piece involves the decisions political parties make to target different segments of the electorate. We posit that the likelihood that any given party will initiate efforts to incorporate a particular subgroup of the population into its constituency is contingent upon the expected returns of these efforts in terms of votes (see, e.g., Jusko 2009).

\section{Left Parties, Poor Voters, and Inequality}

This brings us to the interplay between left parties and low-income voters under different conditions of inequality. Over the years, the study of income as an individual-level political resource has received considerable attention, though rarely in isolation from related phenomena of social stratification like class, social status, or education or separate from socio-economic status ("SES") as an encompassing concept for such social differences. Scholars have long assumed that they shape political engagement based on the empirical finding that individuals with more material, cognitive, and other resources (such as time) participate in politics at higher rates across a variety of countries (Jennings, van Deth, et al. 1989; Verba, Schlozman, and Brady $1995)^{3}$

If individuals with higher levels of resources in the form of income participate more, then aggregate variation in turnout is to a greater extent due to variations in the propensity of lower income voters to turn out. Assuming, on the basis of long-standing historical patterns of electoral democracies, that voters with lower incomes are the most natural constituency of left parties, this raises the question of why lower income earners vote more frequently in some countries than 
others. While parties may indeed have reason to be skeptical of the ability of low-income voters to turn out even if they target policy benefits at them, left parties in some countries clearly seem less skeptical of low income voters than left parties in other countries. ${ }^{4}$

To explain why, we model left parties' choices to mobilize lower income voters. The decision to target low income citizens with mobilization efforts $(m)$ involves material and organizational costs (c) and a potential electoral benefit (b). In weighting these costs and benefits, parties face uncertainty about the low income voter's type - that is, whether she will respond to mobilization efforts. If the Left Party has reasons to think that low income voters will ignore its mobilization efforts, it is better off devoting its scarce resources to some other group. But if the Left Party has reason to expect that mobilization efforts may be successful, then it has every incentive to target low income voters.

Assuming that poorer people are less likely to engage in politics and assuming that higher levels of inequality mean more people in the lower income sector of society, we can define the probability that low income voters will ignore the targeting efforts by left parties (p) as a function of the skew of the income distribution. Following the standard Meltzer and Richard (1981) model, $p=1-\frac{y^{m}}{y}$ and $(1-p)=\frac{y^{m}}{y}$, where $y^{m}$ is the median voter's income and $y$ defines the average income in society. ${ }^{1}$ Because the average income exceeds the median income, $\mathrm{p}$ is always positive. The more the average income exceeds the median income, the more pronounced the income skew, increasing the value of $p$ and thus the odds that low income voters will ignore mobilization by the Left Party.

\footnotetext{
${ }^{1}$ Our thanks to Francesc Amat for suggesting this strategy to model the impact of the skew of the income distribution on $\mathrm{P}_{\mathrm{L}}$ 's strategy.
} 
Under what conditions one should we then expect left wing parties to either pursue or ignore low income voters? In addressing this question, we consider first a scenario in which the political left is dominated by a single party, which we call $\mathrm{P}_{\mathrm{L}}$. Subsequently, we analyze how this choice is altered by the entrance in the political market of a new, smaller, organization challenging the dominance of $\mathrm{P}_{\mathrm{L}}$. We refer to this new challenger in the political market as $\mathrm{P}_{\mathrm{C}}$.

\section{Scenario 1: A Dominant Left-Wing Party's Decision to Mobilize Low Income Voters}

A single party on the left of the political spectrum confronts the following decision problem when it seeks to maximize its expected utility (EU):

$$
E U(m)_{P_{L}}=(b-c)(1-p)-c(p)>0
$$

Substituting $\mathrm{p}$ and (1-p) into expression (1) allows us to identify the conditions under which the main left-wing party opts for mobilizing low income voters:

$$
\frac{y^{m}}{y}>\frac{c}{b}
$$

Expression (2) captures the direct link between the level of inequality and the incentives of dominant left parties $\left(\mathrm{P}_{\mathrm{L}}\right)$ to target low-income voters: as inequality increases - that is, as the gap between the median and the average increases - it becomes harder for parties to clear the cost/benefit threshold that makes it rational for them to direct mobilization efforts towards low income citizens. Thus:

H1a. Higher levels of income inequality produce lower (higher) incentives for dominant left parties to target lower (middle and higher) income voters.

H1b. Higher levels of inequality, particularly in the lower half of the income distribution, should lead to lower levels of aggregate voting turnout. 


\section{Scenario 2: Modeling Decisions by Left Parties in a Competitive Environment}

While these results are of great interest by themselves, the fact is that dominant left-wing parties $\left(\mathrm{P}_{\mathrm{L}}\right)$ in many advanced industrial societies face some competition within their own political spectrum for the support of low income voters. As a result, their decision depends not only on how structural conditions shape the behavior of low income citizens but also, and critically, on the presence of a challenger on the left $\left(\mathrm{P}_{\mathrm{C}}\right)$. Figure 1 presents the sequence of the interaction between the main party and the challenger at the left of the political spectrum.

Several assumptions are implicit to Figure 1: first, parties must choose the level of mobilization effort targeted at low income voters. If $\mathrm{m}=0$, parties are effectively ignoring low income voters. In turn, $\mathrm{m}>0$ reflects a decision by left-wing parties to target low income voters to some extent. Second, the level of mobilization effort chosen by $\mathrm{P}_{\mathrm{L}}\left(\mathrm{m}_{\mathrm{L}}\right)$ is known to $P_{C}$ before it sets its own strategy. One can think of $\mathrm{m}_{\mathrm{L}}$ exhibited in the previous election as a reasonable estimate of the level of effort that is likely in the current election. Third, we also assume that $\mathrm{P}_{\mathrm{L}}$ knows that there will be some competition by a challenger and, more importantly, that $\mathrm{P}_{\mathrm{L}}$ is aware that its own mobilization efforts $\left(\mathrm{m}_{\mathrm{L}}\right)$ will condition those of the challenger $\left(\mathrm{m}_{\mathrm{C}}\right)$. None of these assumptions strike us as particularly unrealistic. In this framework, the behavior of $\mathrm{P}_{\mathrm{L}}$ and $\mathrm{P}_{\mathrm{C}}$ in the electoral market is analogous to that of a dominant company and a challenger in a standard product market. The question is how the dominant party adjusts its strategy in response to the prospect of competition by a new entrant.

In what follows we use a variant of the Stackelberg model of oligopolistic competition (Varian 2003: 474-480) to model the strategic choices of $\mathrm{P}_{\mathrm{L}}$ and $\mathrm{P}_{\mathrm{C}}$. In the original model, companies adjust their choices of prices and quantities to the presence of a new competitor. In our application, parties adjust their mobilization efforts $(\mathrm{m})$ in response to the entrance of a new 
competitor in the political market. The equilibrium solution in this type of game is defined by the point at which the lowest possible indifference curve of $\mathrm{P}_{\mathrm{L}}$ crosses the reaction function of $\mathrm{P}_{\mathrm{C}}-$ that is, by the point at which the marginal profit and the marginal cost associated with additional mobilization efforts are the same for both parties $\left(m_{L}^{*}, m_{C}^{*}\right)$.

(Figure 1 about here)

We proceed to identify such an equilibrium and elaborate its analytical implications. The game is solved by backward induction: we identify first the optimal strategy of $\mathrm{P}_{\mathrm{C}}$ to subsequently study how $\mathrm{P}_{\mathrm{L}}$ chooses its optimal mobilization effort given the presence of a challenger. Both parties want to maximize the level of electoral benefit (b), given their own mobilization strategies (choice of the level of effort, $\mathrm{m}$ ) and those of their competitors. Recall that the level of mobilization effort of the main party $\left(\mathrm{m}_{\mathrm{L}}\right)$ is given by the time $\mathrm{P}_{\mathrm{C}}$ confronts its strategic choice. In other words, $\mathrm{m}_{\mathrm{C}}$ is a reaction to $\mathrm{m}_{\mathrm{L}}$. More specifically, $\mathrm{P}_{\mathrm{C}}$ 's maximization problem is given by:

$\operatorname{Max} b\left(m_{L}+m_{C}\right) m_{C}-c_{C}\left(m_{C}\right)$

where $\mathrm{b}$ and $\mathrm{c}$ represent, respectively, the electoral profit and the mobilization costs of the party deciding on the level of mobilization targeted towards poorer voters $(\mathrm{m}) . \mathrm{P}_{\mathrm{C}}$ will choose a level of mobilization effort such that the marginal electoral benefit (b) equals the marginal cost (c). Using a standard demand function, this yields the following electoral profit (b) function for $\mathrm{P}_{\mathrm{C}}$ $b\left(P_{C}\right)=\left[\alpha-\beta\left(m_{L}+m_{C}\right)-c_{C}\right] m_{C}$

Differentiating (4) with respect to $\mathrm{m}_{\mathrm{C}}$ and solving for $\mathrm{m}_{\mathrm{C}}$, we obtain the optimal level of mobilization effort for the challenger $\left(\mathrm{P}_{\mathrm{C}}\right)$

$$
m_{C}^{*}=\frac{\alpha-\beta m_{L}-c_{C}}{2 \beta}
$$


An interesting insight emerges from this result: there is an inverse relationship between the level of mobilization set by $\mathrm{P}_{\mathrm{L}}$ and the optimal level of effort by $\mathrm{P}_{\mathrm{C}}$. Because the main party on the left moves first, this information is very relevant for its own strategy. As a result the maximization problem for $\mathrm{P}_{\mathrm{L}}$ becomes

$\operatorname{Max} b\left(m_{L}+m_{C}\right) m_{L}-c_{L}\left(m_{L}\right)$

s.t. $m_{C}=\frac{\alpha-\beta m_{L}-c_{C}}{2 \beta}$

Substituting we obtain

$$
b\left(P_{L}\right)=\left[\alpha-\beta\left(m_{L}+\left(\frac{\alpha-\beta m_{L}-c_{C}}{2 \beta}\right)\right)-c_{L}\right] m_{L}
$$

Finally, differentiating (7) with respect to $\mathrm{m}_{\mathrm{L}}$ and solving for $\mathrm{m}_{\mathrm{L}}$, we obtain the optimal level of mobilization effort of $\mathrm{P}_{\mathrm{L}}$ given the presence of $\mathrm{P}_{\mathrm{C}}$.

$$
m_{L}^{*}=\frac{\alpha+c_{C}-2 c_{L}}{2 \beta}
$$

Note that, because $\mathrm{P}_{\mathrm{L}}$ moves first, expression (8) also represents the effort to target low-income citizens finally adopted by $\mathrm{P}_{\mathrm{L}}$. In turn, establishing the mobilization effort of the challenging party requires substituting (8) into (5). This completes the solution of the game, yielding:

$$
m_{C}^{*}=\frac{\alpha+c_{L}-3 c_{C}}{4 \beta}
$$

Expressions (8) and (9) offer two insights for studying the relationships among inequality, party competition, and mobilization strategies pursued by left parties. First, there is a positive relationship between the optimal level of effort by $\mathrm{P}_{\mathrm{L}}$ and the costs incurred by $\mathrm{P}_{\mathrm{C}}$. Interestingly, however, $\mathrm{P}_{\mathrm{C}}$ faces steeper organizational costs as a result of the earlier move by $\mathrm{P}_{\mathrm{L}}$ and is constrained to limit its efforts, as reflected by the fact that its output is bound to be lower than that of the main party of the left. In other words, the anticipatory increase in mobilization 
effort by $\mathrm{P}_{\mathrm{L}}$ limits the output to be obtained by the challenger. As a result, in the presence of a competitor, the main party of the left has every incentive to increase its mobilization effort $\left(m_{L}\right)$. Second, and more importantly, this incentive applies even in the presence of high levels of inequality. Recall from expression (2) above that mobilization costs increase in inequality. The results of the analysis suggest that high levels of inequality, while increasing the costs for $P_{L}$, increase the costs for $\mathrm{P}_{\mathrm{C}}$ to a relatively greater extent, thus reinforcing the preemptive effects of an increase in the mobilization effort towards low income voters by $P_{L}$. Thus:

H2a. A left competitor moderates the effect of inequality on parties' incentives to target low income voters. While dominant left-wing parties have fewer incentives to do so in the absence of competition, the presence of a challenger from the left creates incentives to mobilize low-income voters, thus counteracting the negative impact of inequality on parties' incentives to concentrate their efforts on low income voters.

H2b. Accordingly, we would expect that the negative association between inequality and turnout at the aggregate level to be muted by the presence of several parties on the left side of the political spectrum.

We now turn to evaluating these claims at the aggregate level of national elections, using data from OECD countries for the period from 1980 to 2002 as well as at the level of individual voters with the help of surveys conducted in the industrialized democracies.

\section{Income Inequality and Electoral Participation at the Aggregate Level}

To examine the argument that aggregate differences in turnout are driven by levels of inequality and left party competition we require information about inequality, party systems, and turnout for a sufficient number of elections that cover a sufficient number of countries, as well as estimation methods that allow us to disentangle the potential reciprocity between inequality and voter turnout as posited by our theory. 


\section{Data and Measures}

Two ways of measuring voter turnout predominate in the literature: electoral participation as a percentage of the country's voting age population, and participation as a percentage of registered voters, with the former more common than the latter (Geys 2006; Blais 2006). We employ both measures here, using data collected by the International Institute for Democracy and Electoral Assistance (IDEA). To measure income inequality, we rely on data collected by the Luxembourg Income Study (LIS), the only truly cross-nationally collaborative effort designed to collect income inequality data that are comparable across countries. We use LIS data to calculate our primary independent variable, income inequality in the lower half of the income distribution (for details on variables, see the appendix). Finally, to measure left party competition, we calculate the effective number of left parties competing for votes based on the well-known Laakso-Taagepera index (which adjusts the number of parties for their size).

In addition, to minimize omitted variable bias, we control for other factors that could potentially account for the association between inequality and turnout (see the review by Blais 2006). Among these, the electoral system is among the most prominent ones (Blais 2006; see also Iversen and Soskice 2006). Such institutional differences are particularly important in the context of this study, as we see them as a potential explanation for the sustainability of political bargains over time. ${ }^{5}$ To measure these, we rely on a measure of the disproportionality of the electoral system in the form of the Gallagher index. ${ }^{6}$

In addition, the estimation model contains a number of variables previously identified as potentially relevant determinants of cross-national differences in turnout levels (cf. Blais 2006; Geys 2006). These include the competitiveness of the election, the size of the voting age population $(\log )$, the level of economic growth, the share of votes obtained by labor oriented 
parties, whether elections are held on a holiday, whether there is a system of automatic registration, the degree of compulsory voting, and whether the system of representation is unicameral (see, e.g., Franklin 2004; Gray and Caul 2000 for detailed explanations for each of these). While the literature is divided over the robustness of effects for some of these variables (see the comprehensive review by Blais 2006), we err on the side of inclusiveness.

\section{Estimation Method}

A key analytical issue is the possibility that inequality is endogenous to electoral participation. The argument that left parties and low income voters engage in an exchange whereby left parties promise and maintain large and generous welfare states, which lead to a more equal distribution of income, ${ }^{7}$ implies that there is good reason to believe that inequality drives participation but also that it could work in the reverse - that is, that participation drives (in)equality by creating demands for social protection (cf. Mueller and Stratman 2003; Pontusson and Rueda 2010). Because inequality effects can also be seen as the mirror image of welfare states, it may well be endogenous to participation (Mahler 2002; see also Huber and Stephens 2001; Franzese 2000). ${ }^{8}$

This potential reciprocity between inequality and participation requires that we properly identify the causal effect of inequality on turnout rates, rather than simply assume that it runs from the former to the latter, as has been the case in all research to date. To address this issue in our estimations, we rely on an instrumental variable approach to estimate two-way simultaneous equation models. In the first stage, we instrument inequality with exogenous variables; in a second stage, we use the predicted values of the dependent variable of the first-stage equation to estimate the impact of aggregate inequality on the aggregate levels of turnout. 
To instrument inequality in the first stage, we estimated a model where income inequality is a function of the ideological profile of government and the overall degree of economic coordination (Hall and Gingerich 2004). To say that government ideology and economic coordination are our instruments implies that we expect these variables to be directly related to levels of inequality but not to electoral participation. The underlying motivation for using economic coordination is the idea, strongly supported by cross-national statistical evidence, that institutions of economic coordination (e.g., collective bargaining institutions, centralization of wage setting, etc.) produce compressed wage and income inequality differentials via collective bargaining (cf. Wallerstein 1999). Government ideology is expected to shape income inequality through partisan governments implementing egalitarian policies, also a finding consistently supported by statistical evidence (Beramendi and Anderson 2008).

Satisfactory performance of these variables as instruments requires that they account for variation in the potentially endogenous variable (here: income inequality), but the restriction assumption for an instrument also requires that they be unrelated to the error term of the second equation. Regressing levels of inequality on economic coordination and government ideology in a first stage estimation, we obtain an r-squared of .54, thus satisfying the first criterion. To examine whether the second criterion - that the instruments be unrelated to the error term of the second equation - is met, we modeled the remaining error in the second stage dependent variable as a function of economic coordination and government ideology. This estimation shows that economic coordination and government ideology are unrelated to the error term in the second stage regression - that is, they are not unobserved determinants of the dependent variable. ${ }^{9}$ As a second test of the validity of the instruments, we estimated single-equation two-stage least squares models and conducted a test of over-identification (results shown in the appendix). In 
these estimations, the error terms of both equations are considered simultaneously and all control variables of the second equation are also controls in the first equation. This allows us to judge the validity of the instrument. The chi-squared statistic for Sargan's test of overidentifying restrictions is not significant, indicating that the instruments are valid.

The estimations are based on data for ninety-six elections across sixteen OECD countries (described in detail in the appendix). ${ }^{10}$ Given the unbalanced nature of our panel, and because we have more cross-sectional units than time periods, we estimate our models using OLS with robust standard errors, with the cases clustered by cross-sectional unit (see Bradley et al. 2003 for a detailed explanation). To ensure the robustness of our results, we report one set of results that employs the percentage of registered voters as the dependent variable, and another that measures turnout as the percentage of the voting age population. Both models include an interaction term between inequality and the number of left parties to capture the presumed conditional effect of political competition on the left and inequality on turnout.

\section{Results}

The estimation results presented in Table 1 support our argument. The effects of inequality can be interpreted as its independent influence when the interaction term is zero - that is, when there is no left party in the country. The results reveal that, after controlling for endogeneity, higher levels of inequality among lower income voters lead to lower levels of turnout. Regardless of whether we measure turnout as a percentage of registered voters or the voting age population, income inequality exerts a consistent, independent, and significantly negative impact on turnout. ${ }^{11}$ In fact, the coefficients are virtually identical across the two different ways of measuring electoral participation. 
We examined the robustness of these results in several ways. Among these, we estimated models without control variables and additional models that included dummy variables for countries that may be outliers. ${ }^{12}$ These results show that the effects for income inequality are very robust. In addition, we sought to put the substantive effects in perspective. Based on the multivariate estimates (and holding all other variables at their mean), we calculated that moving from the most equal income distribution to the most unequal leads to a 42 percent drop in the predicted level of turnout as a proportion of registered voters (from $94 \%$ to $52 \%$ ), with a turnout level of $80 \%$ at the mean level of inequality. Income inequality produces a similar effect when we measure turnout as a proportion of the voting age population; here, the difference in turnout between the most equal and most unequal countries is 46 percent (91\% v. $45 \%$ ), with a turnout rate of 75 percent in the country with the mean level of inequality.

More importantly, however, for our analyses, the coefficient for the interaction term of inequality and left party competition is positive and significant. This provides clear evidence for our central hypothesis and suggests that the presence of competitors from the left shapes the impact of inequality on turnout: greater competition on the left moderates the effect of inequality on turnout, thus diminishing the negative impact of inequality on whether people vote. Put simply, when there is partisan competition on the left, inequality's effects on turnout are reduced.

\section{[Table 1 about here]}

Several of the control variables have significant effects. All else equal, holiday voting diminishes turnout, while compulsory voting increases it. We also find that larger electorates (in relation to the total population) are associated with higher levels of voter turnout. Finally, unicameralism, the competitiveness of elections, automatic registration, economic growth, and the vote share of left parties do not have consistent effects on turnout. Given that these variables 
are merely included as controls, and given the inconsistent and sometimes contradictory effects of these variables commonly documented in the literature (Blais 2006; Geys 2006), we do not discuss them in greater detail here. ${ }^{13}$

Taken together, then, the results support Hypotheses 1 and 2 above: they are consistent with the argument outlined in the paper, even after we account for the potential endogeneity of inequality. Moreover, the results provide strong evidence that income inequality reduces voter turnout but that competition on the political left mutes the negative effect that inequality has on voter turnout. However, while they are consistent with the potential mechanism highlighted in our argument, they do not speak to it directly. To assess the validity of our theoretical claims further, we turn to an analysis of the mobilization of individual voters.

\section{Inequality and Mobilization: Individual Level Analyses}

\section{Data and Measures}

Examining whether individual level evidence is consistent with our claims about parties' incentives to mobilize poor voters requires surveys from a number of countries with varying levels of inequality and left party competition. Fortunately, such surveys are available as part of the second wave of the Comparative Study of Electoral Systems (CSES) project conducted between 2001 and 2006 (www.cses.org). These election surveys were designed to be comparable across countries with regard to variables included in the surveys, the wording of the questions, and so forth. From the set of countries included in the CSES, the relevant individual-level survey items and macro-level inequality measures (described below) were available for a set of fourteen OECD countries that overlap almost completely with the set of countries included in the aggregate analyses. $^{14}$ 
Estimating the impact of income inequality and partisan competition on people's responses requires that the survey data be pooled because our model requires macro-level variation in inequality and party competition, which are expected to interact with an individuallevel variable (income) to shape mobilization. The survey data were merged with macro-level measures of income inequality and partisan competition.

The election surveys classify respondents' household income by quintiles. This allows us to identify respondents whose income falls into various income categories (based on national currency levels). As a result, the income variable is insensitive to differences in income levels or purchasing power across countries and thus simply captures respondents' income relative to others in society. To measure parties' mobilization efforts, we analyze a question that asked respondents whether political parties contacted them during the election campaign. ${ }^{15}$

To properly isolate the impact of our key independent variables and avoid omitted variable bias, we sought to control for a number of factors that may affect our dependent variables. These variables fall into the categories of demographic characteristics (age, gender, education, employment, marital status), associational membership (unions), and political ideology (described in greater detail in the appendix). We estimated models with and without country-level controls (in models with controls we included those variables that had a significant impact on turnout as shown in Table 1).

\section{Estimation and Results}

To assess whether there are significant differences in mobilization rates across income groups, depending on levels of inequality and left party competition in a country, we split voters into those earning below the median income in the country and those at or above the median income, and estimated the interactive effects of income inequality and left party competition on 
rates of contacting in these two groups of respondents. ${ }^{16}$

As the results of the multilevel logistic regressions reported in Table 2 reveal, ${ }^{17}$ the variable of primary interest - the interaction between partisan competition and inequality - shows very consistent effects that clearly support our theoretical priors. Specifically, the results show that poor voters are more likely to be mobilized in unequal countries with more than one left party, while inequality paired with only one left party diminishes such mobilization. In stark contrast, the mobilization of middle and higher income earners thrives in unequal societies with fewer left parties. In turn, lower income voters are significantly more likely to be contacted if they live in countries with higher levels of inequality in the bottom half of the income distribution and effective competition on the left side of the political spectrum (Models 1 and 2). Finally, the joint presence of inequality and left party competition does not affect contacting rates of higher income earners (Model 3) or in fact marginally decreases them (Model 4).

To ensure the robustness of these results beyond estimating models with and without macro-level controls, we conducted two additional analyses. First, to check that the results were insensitive to our operationalization of relative income, we re-estimated our models that compare only citizens in the lowest income quintile in the electorate with other voters. These analyses yielded results that were similar to those reported above, with significant coefficients for the competition-inequality interaction term. Second, we examined whether our results are sensitive to the inclusion of specific countries - in particular, the United States, Australia, and Switzerland; we find that they are not.

[Table 2 about here]

How consequential, then, are these differences in the joint effects of income inequality and partisan competition on voters? In particular, how consequential are they for lower and 
higher income voters? To better understand the estimated substantive impact of inequality and left party competition on the dependent variables, we calculated how typical respondents' reports of contacting vary across income groups with different levels of income inequality and competition using the coefficients reported in Table 2. To summarize these various predicted probabilities, we then calculated the gaps in contacting between high and low income voters under different macro-level conditions.

The results of these calculations are shown in Figure 2. The two lines indicate the difference in the odds that high and low income respondents were contacted; positive values indicate that high income earners were more likely to be contacted, while negative values indicate that low income earners were more likely to be contacted during the campaign. The dashed line demonstrates the rich-poor contacting gap under conditions of partisan competition on the left, while the solid line demonstrates the gap under conditions of no competition.

Looking first at contacting under conditions of no left party competition, the solid line shows that the gap in contacting is virtually zero when inequality is very low. This suggests that there is no difference in the rates of contacting lower and higher income earners when there is one dominant left party and very low levels of income inequality. However, as inequality grows, the mobilization gap between rich and poor voters widens substantially to over twenty percent at the highest level of income inequality. Thus, high income inequality coupled with only one left party leads to more mobilization of higher income earners than lower income earners.

In contrast, the presence of competition from the left decreases the contacting gap, even at higher levels of inequality. In fact, when partisan competition on the left is particularly fierce, a ten percent probability difference in being contacted in favor of higher income voters at low to moderate levels of income inequality completely vanishes and turns into a contacting gap in 
favor of lower income voters at high levels of inequality. Interestingly, the graph also reveals that average levels of contacting gaps - across different conditions of inequality and partisan competition - are small, though slightly positive. This suggests, once more, that understanding the impact of inequality on turnout requires understanding the combined effects of individual income, overall income inequality, and the incentives of left parties.

[Figure 2 about here]

\section{Conclusions}

Economic inequality shapes the quality of democratic life. Greater inequality concentrates power among a smaller group of people and increases politicians' responsiveness to a smaller group of advantaged citizens (Bartels 2008; Dahl 1971; Schattschneider 1960). Because of this, some have questioned the legitimacy of elections that are less than fully representative of different segments of the electorate (Piven and Cloward 1988). While economic inequality is clearly an important normative issue for students of democratic politics, relatively little is known about its effect on democratic engagement. This paper examined the relationship between income inequality and electoral turnout in rich democracies by focusing on the pivotal group of voters who are thought to constitute the core of less involved citizens - poorer voters and the political parties with the most to gain from their participation - parties on the left. We argued that countries' income distributions and the presence of left party competitors provide systematically different incentives for left parties to mobilize lower income voters, but also distinct incentives for lower income voters to turn out to vote.

We formalized our argument as a model of party mobilization. It predicts that left party competition fosters the mobilization of lower income voters. Specifically, higher levels of income inequality reduce the incentives of dominant left parties to target lower income voters, 
and, by implication, increase these parties' incentives to concentrate their efforts on the mobilization of middle and higher income voters, but only under certain political conditions. Our model also predicts that the presence of a competitor from the left moderates the effect of inequality on the incentives to target low income voters. Specifically, presence of a challenger from the left creates incentives to mobilize low-income voters, thus counteracting the negative impact of inequality on parties' incentives to concentrate their efforts on low income voters. Combined, these processes produce higher electoral turnout among lower income voters in more inegalitarian countries, so long as the dominant left party has competition.

We tested our theory with data on elections in OECD countries between 1980 and 2002 and with the help of survey data from the Comparative Study of Electoral Systems. Our results show, first, that greater inequality in the lower half of the income distribution is conducive to lower aggregate levels of voter turnout. Accounting for the likely endogeneity between electoral participation and inequality, we find that countries with more equal incomes below the median also have higher levels of turnout, while countries with higher levels of income inequality have lower levels of turnout. However, the negative impact of inequality on turnout is significantly diminished in countries with greater partisan competition on the left.

We also examined the mechanism that we argue underlies this relationship by estimating how income inequality affects individual voters' reports of being mobilized. Using election surveys collected between 2001 and 2005 in fourteen advanced industrialized countries, we found that there is a gap in contacting rates, with higher income earners reporting more frequent mobilization. Our results also showed that lower income voters were particularly unlikely to be contacted by political parties in countries with more unequal distributions of income and where 
the dominant left party did not have direct competitors. In contrast, low income voters were more likely to be contacted in more unequal countries with party competition on the left.

These findings have several implications for our understanding of the connections among material wellbeing, electoral participation, party behavior, and the quality of democracy. For one, while students of mass political behavior have long viewed the macroeconomy as an important influence on people's beliefs that government is legitimate and effective and on citizens' propensity to be involved in the political process, few studies have investigated the link between income inequality and participation across countries. ${ }^{18}$ Our study suggests that relative wellbeing is a critical factor shaping democratic participation.

Our findings also shed light on the role parties play in mobilizing voters. For one, they provide a comparative context for the U.S. case - the country with the most unequal income distribution among advanced industrialized democracies, no direct competitor to the dominant left party, and concomitant low levels of mobilization among poorer voters. Moreover, our results imply that such practices and results are neither inevitable nor omnipresent across democracies. In fact, the significantly lower mobilization rates among low income Americans are consistent with our theory not simply because of high levels of inequality but because of the absence of a direct competitor for the Democratic Party (Karp, Banducci, and Bowler 2008).

Our results also contribute to what we know about turnout by connecting macro-level conditions - the shape of the income distribution in society and political competition - with individual voters' incentives. Moreover, they suggest that macro-level factors not only shape voters' incentives but also the strategies parties pursue. Thus, by integrating both micro- and macro-level explanations of electoral participation, our analysis enhances our understanding of how citizens and parties behave in countries with very different configurations of welfare states 
and inequality. More generally, it suggests that combining the political context in which people make decisions - in this case, a country's performance in the form of income inequality - with critical individual-level variables - in this case, individuals' income - leads to a more general model and comprehensive understanding of the forces that shape political behavior.

By illuminating the link between inequality, partisan competition, and turnout, the paper also points to areas for further research. The sustainability of the income and turnout conditions described above is anchored in a number of institutional differences that relate to both the design of the electoral system and the functioning of different systems of social protection - the nuts and bolts behind inequality (Iversen and Soskice 2006; Pontusson 2005). At the core of the exchange between left parties and poor voters are the welfare state and the institutionalization of high levels of decommodification (Esping-Andersen 1990; Scruggs and Allan 2003). The comparative analysis of electoral turnout has much to gain from a more detailed exploration of the links between these institutional features and the incentives of both parties and individuals (see, e.g., Iversen and Soskice 2006). An example is recent work by Pontusson and Rueda (2010), which shows that left party positions and party system polarization are to a significant degree shaped by levels of income inequality and the mobilization of low income voters.

In addition, it would be important learn more about the feedback mechanisms between inequality and turnout, and how they affect the sustainability of mobilization and turnout conditions identified in the paper. Our model would predict that, by virtue of the interplay between parties and voters, significant transformations in terms of distributive outcomes across advanced industrial societies should be reflected in patterns of electoral turnout. Existing evidence suggests that increases in inequality are indeed associated with a greater number of labor market "outsiders", reduced mobilization efforts of labor unions and left-wing parties, and 
less political involvement of societal sectors situated at the extremes of the distribution (Leighley and Nagler 2003; Rueda 2005). However, as Rueda has noted, left parties do not treat all low income voters the same. Thus, changes in income distributions have the potential to affect turnout differently, depending on whether left parties pursue electoral strategies that benefit only certain segments of lower income voters or on occasion do not benefit them at all (Rueda 2005). Currently, the political and electoral consequences of changing inequalities are still largely unexplored territory. 


\section{A. Descriptive Statistics}

\section{Country Level Data}

\begin{tabular}{lcccc}
\hline Variable & Mean & Std.Dev. & Minimum & Maximum \\
\hline Turnout & .74 & .13 & .34 & .94 \\
Inequality below median & 2.01 & .32 & 1.58 & 2.80 \\
Effective no. of left parties & 1.85 & .87 & 1 & 4.13 \\
Disproportionality & 6.41 & 5.95 & 1.29 & 18.65 \\
Competitiveness of election & 9.01 & 6.64 & .07 & 24.91 \\
Growth & 2.64 & 2.32 & -6.30 & 10.70 \\
Voting share of left parties & .33 & .15 & 0 & .54 \\
Holiday & .53 & .50 & 0 & 1 \\
Automatic registration & .81 & .40 & 0 & 1 \\
Voting age population $(\log )$ & 16.20 & 1.34 & 14.55 & 19.14 \\
Unicameralism & .36 & .48 & 0 & 1 \\
Compulsory voting & .61 & 1.08 & 0 & 3 \\
\hline
\end{tabular}

Individual Level Data

\begin{tabular}{lllll}
\cline { 2 - 5 } & Mean & Std. Dev. & Min. & Max. \\
\hline Contacted & .26 & .44 & 0 & 1 \\
Lower income & .41 & .49 & 0 & 1 \\
Age & 47.66 & 16.41 & 16 & 100 \\
Gender & 1.50 & .50 & 1 & 2 \\
Education & 5.57 & 1.74 & 3 & 8 \\
Left-right ideology & 5.13 & 2.23 & 0 & 10 \\
Union membership & .32 & .47 & 0 & 1 \\
Unemployed & .04 & .19 & 0 & 1 \\
Part-time employed & .12 & .33 & 0 & 1 \\
Married & .64 & .48 & 0 & 1 \\
\hline
\end{tabular}




\section{APPENDIX B. List of Left Parties and Elections}

\section{Left Parties}

Australia: Labour Party (ALP)

Austria: Socialist Party (Sozialdemokratische Partei Österreichs, SPÖ)

Belgium: Francophone Socialist Party (Parti Socialiste, PS), Social Progressive Alternative/SPIRIT (Sociaal Progressief Alternatief, SP.a/SPIRIT) (until 2001: Flemish Socialist Party (SP)), Communist Party (Kommunistische Partij van Belgie/ Parti Communiste de Belgique, KPB/PCB)

Canada: CCF, New Democratic Party

Denmark: Social Democrats (Socialdemokratiet, SD), Socialist People's Party (Socialistisk Folkeparti), The Unity List (Enhedslisten, EL)

Finland: Social Democrats (Suomen Sosialidemokraattinen Puolue, SDP), Finnish People's Democratic Union (SKDL), Democratic Alternative (DEVA), Left-Wing Alliance (Vasemmistoliitto, VAS)

France: Socialist Party (Parti Socialiste, PS), Extreme/Far Left (Extrême gauche), Communist Party (Parti Communiste Français, PCF)

Germany: Social Democrats (Sozialdemokratische Partei Deutschlands, SPD), Party of

Democratic Socialism (Partei des Demokratischen Sozialismus, PDS)

Ireland: Irish Labour Party, Workers' Party, Democratic Left (joined Labour Party in 2002)

Italy: Socialist Party (in 2001: New PSI (Nuovo PSI)) (Partito Socialista Italiana, PSI), Social Democratic Party (Partito Socialista Democratica Italiano, PSDI), Party of the Democratic Left (Democratici di Sinistra, DS) (reformist wing of the dispanded PCI), Communist Party (Partito Communista Italiano, PCI), Communist Refoundation (RC) (left wing of the dispanded PCI)

The Netherlands: Labour Party (Partij van der Arbeid, PvdA), Socialist Party (Socialistische Partij, SP)

Norway: Labour Party (Det Norske Arbeiderparti, DNA), Socialist Left (Sosialistik Venstreparti, SV) (formerly Socialist People's Party)

Spain: Socialist Party (Partido Socialista Obrero Español, PSOE), Communist Party, United Left

(Partido Communista de España, Izquierda Unida, PCE/PSUC/IU)

Sweden: Social Democrats (Socialdemokraterna, S), Left Party (Vänsterpartiet, V) (formerly Communist Part (Svergies Kommunistiska Parti))

Switzerland: Social Democrats (Sozialdemokratische Partei der Schweiz/Parti Socialiste Suiss, SPS/ PSS)

United Kingdom: Labour Party

USA: Democratic Party 


\section{Countries and Elections Included in Aggregate Analyses}

Australia $\quad 1980,1983,1984,1987,1990,1993,1996,1998,2001$

Austria $\quad 1983,1986,1990,1994,1995,1999$

Belgium 1981, 1985, 1987, 1991, 1995, 1999

Canada $\quad 1980,1984,1988,1993,1997,2000$

Denmark 1981, 1984, 1987, 1988, 1990, 1994, 1998, 2001

Finland $\quad 1983,1987,1991,1995,1999$

France $\quad 1981,1988,1995,2002$

Germany $\quad 1980,1983,1987,1990,1994,1998$

Ireland $\quad 1981,1982,1982,1987,1989,1992,1997$

Italy $\quad 1983,1987,1992,1994,1996,2001$

Netherlands $\quad 1981,1982,1986,1989,1994,1998$

Norway $\quad 1981,1985,1989,1993,1997,2001$

Sweden $\quad 1982,1985,1988,1991,1994,1998$

Switzerland 1983, 1987, 1991, 1995, 1999

UK 1983, 1987, 1992, 1997, 2001

United States 1980, 1984, 1988, 1992, 1996, 2000 


\section{Appendix C. Measures and Coding: Country-Level Data}

Turnout, VAP. Valid vote turnout: percentage of voting-age population (VAP) casting valid votes in national elections. Source: International Institute for Democracy and Electoral Assistance (IDEA) (www.idea.int).

Turnout, Registered Voters. Percentage of registered voters who cast votes in national elections. Source: IDEA (www.idea.int).

Government partisanship. Percentage of total cabinet posts held by social-democratic and other left parties, weighted by days. Source: Armingeon, Beyeler, and Menegale, Comparative Political Dataset. Degree of economic coordination. Scale ( 0 to 1 ) that measures the degree of coordination both within the labor market and within the area of corporate governance. Source: Hall and Gingerich (2004).

Inequality below median. Ratio between the percentile 50 and the percentile 10 equivalized disposable household income inequality. Source: Luxembourg Income Study Disproportionality. Gallagher least index of electoral system disproportionality. Square root of half the sum of the squares of the difference between percent of vote and percent of seats for each party. For two most recent legislative elections. Source: Michael D. McDonald, Binghamton University.

Effective number of left parties. Calculated by the Laakso and Taagepera (1979) formula of the effective

number of electoral parties: $E N E P=\frac{1}{\sum v_{i}^{2}}$ where $v_{i}$ is the percent of votes obtained by the $i^{\text {th }}$ left party as a proportion of all vote shares won by left parties.

Competitiveness of the election. Difference between vote shares of the two largest parties. Sources: Mackie and Rose $(1991 ; 1997)$, Electoral Studies, and European Journal of Political Research. Growth. Percent change in GDP in current international \$'s (in thousands), purchase power parities at the time of the survey. Source: World Development Indicators CD-ROM (2003).

Voting share of left parties. Sum of total vote shares in election for self-identified labor, communist, socialist, or social democratic parties. Sources: Mackie and Rose (1991; 1997), Electoral Studies, and 
European Journal of Political Research. Party coding: Lane, McKay, and Newton (1997), except for United States, where we count the Democratic Party as the left party.

Voting holiday. Elections held on weekend or holiday (1); other (0). Source: Gray and Caul (2000).

Automatic registration. Automatic voter registration (1); other (0). Source: Gray and Caul (2000).

Voting age population (log). VAP: UN Demographic Yearbooks (United Nations, 1950-1993) and the US

Bureau of the Census IDB (http://www.census.gov/ipc/www/idbnew.html)

Unicameralism. Unicameral legislature (1); other (0).

\section{Appendix D. Measures and Coding: Individual Level Data}

Contacted. Based on survey question: "During the last campaign did a candidate or anyone from a political party contact you to persuade you to vote for them?” Yes (1), no (0).

Lower income. Based on income quintiles. Coded (1) if respondent's household income is below the median quintile, $(0)$ otherwise.

Age. Actual age of respondent (in years).

Gender. Male (1), female (0).

Education. Respondent's level of education. 8 point scale. Categories include "none" (1), "incomplete primary" (2), "primary completed" (3), "incomplete secondary" (4), "secondary completed" (5), "postsecondary trade/vocational school" (6), "university undergraduate degree incomplete" (7), and to "university undergraduate degree completed" (8).

Left-right ideology. Based on survey question. "In politics people sometimes talk of left and right. Where would you place yourself on a scale from 0 to 10 where 0 means the left and 10 means the right?"

Union Membership. Yes (1), no (0).

Unemployed. Yes (1), no (0).

Part-time employed. Yes (1), no (0).

Married. Yes (1), no (0). 


\section{References}

Aguilar, Edwin E., \& Alexander C. Pacek. (2000) Macroeconomic conditions, voter turnout and the working-class/economically disadvantaged party vote in developing countries. Comparative Political Studies 33 (8): 995-1017.

Austen-Smith, David. (2000) Redistributing income under proportional representation. Journal of Political Economy 108 (6):1235-1269.

Bartels, Larry. (2008) Unequal democracy: The political economy of the new gilded age. New York: Russell Sage Foundation, and Princeton: Princeton University Press.

Beramendi, Pablo, \& Christopher J. Anderson. 2008. Income inequality and democratic representation. In Democracy, inequality, and representation: A comparative perspective, ed. Pablo Beramendi and Christopher J. Anderson. New York: Russell Sage Foundation.

Beramendi, Pablo, \& Thomas R. Cusack.2009. Diverse disparities: the politics and economics of wage, market, and disposable income inequalities. Political Research Quarterly 62 (2): 257-275.

Blais, André. (2000) To vote or not to vote: The merits and limits of rational choice theory. Pittsburgh: University of Pittsburgh Press.

Boix, Carles. (2003) Democracy and redistribution. New York: Cambridge University Press. Bradley, David, Evelyn Huber, Stephanie Moller, François Nielsen, \& John Stephens. (2003) Distribution and redistribution in postindustrial democracies. World Politics 55 (2): 193228.

Brady, Henry E. (2004) An analytical perspective on participatory inequality and income inequality. In Social inequality, ed. Kathryn M. Neckerman. New York: Russell Sage Foundation.

Brady, Henry E., Sidney Verba, \& Kay Schlozman. (1995) Beyond ses: A resource model of political participation. American Political Science Review 89 (2): 271-294.

Cusack, Thomas R., \& Beramendi, Pablo. (2006) Taxing work. European Journal of Political Research 45 (1): 43-73. 
Dahl, Robert A. (1971) Polyarchy, participation, and opposition. New Haven, CT: Yale University Press.

Esping-Andersen, Gosta. (1990) The three worlds of welfare capitalism. Princeton, NJ: Princeton University Press.

Filer, John E., Lawrence W. Kenny \& Rebecca B. Morton. (1993) Redistribution, income and voting. American Journal of Political Science 37 (1): 63-87.

Franklin, Mark. (2004) Voter turnout and the dynamics of electoral competition in established democracies since 1945. New York: Cambridge University Press.

Franzese, Robert J. (2000) Political participation, income distribution, and public transfers in developed democracies. Working Paper, University of Michigan.

Gallego, Aina. (2007). Inequality in political participation: Contemporary patterns in European countries. University of California, Irvine. Center for the Study of Democracy, paper 0701 (http://repositories.cdlib.org/csd).

Gerber, Alan S., \& Donald P. Green. (2000) The effects of canvassing, telephone calls, and direct mail on voter turnout: a field experiment. American Political Science Review 94 (3): 653-663.

Goodin, Robert, \& John Dryzek. (1980) Rational participation: The politics of relative power. British Journal of Political Science 10 (3): 273-292.

Gray, Mark M, \& Miki Caul. (2000) Declining voter turnout in advanced industrial democracies, 1950 to 1997: The effects of declining group mobilization. Comparative Political Studies 33 (9): 1091-1122.

Gurr, Ted R. (1970) Why men rebel. Princeton, NJ: Princeton University Press.

Hall, Peter A., \& Daniel W. Gingerich. (2004) Varieties of capitalism and institutional complementarities in the macroeconomy: An empirical analysis. Max Planck Institute for the Study of Societies Cologne, MPIfG Discussion Paper 04/5.

Hibbs, Douglas. (1973) Mass political violence. New York: John Wiley. 
Huber, Evelyn, \& John D. Stephens. (2001) Development and crisis of the welfare state. Chicago: University of Chicago Press.

Iversen, Torben, \& David Soskice. (2006) Electoral systems and the politics of coalitions: Why some democracies redistribute more than others. American Political Science Review 100 (2): $165-81$.

Jackman, Robert W. (1987) Political institutions and voter turnout in the industrial democracies. American Political Science Review 81 (2):405-23.

Jennings, M. Kent, Jan van Deth, et al. (1989) Continuities in political action: A longitudinal study of political orientations in three western democracies. New York: De Gruyter and Aldine.

Jesuit, David. (2003) The regional economic dynamics of European electoral politics: participation in national and European contests in the 1990s. European Union Politics 4 (2): $139-164$.

Jusko, Karen L. (2009) Partisan representation of the poor: Electoral geography, strategic mobilization, and implications for voter turnout. Working paper, Stanford University, Department of Political Science.

Karp, Jeffrey A., Susan A. Banducci, \& Shaun Bowler. (2008) Getting out the vote: Party mobilization in a comparative perspective. British Journal of Political Science 38 (1): 91112.

Kenworthy, Lane, \& Jonas Pontusson. (2005) Rising inequality and politics of redistribution in affluent countries. Perspectives on Politics 3 (3): 449-471.

Laakso, Markku, \& Rein Taagepera (1979) Effective number of parties: A measure with application to west Europe. Comparative Political Studies 12 (1): 3-27.

Lane, Jan-Erik, David McKay, \& Kenneth Newton. (1997) Political data handbook OECD countries. New York: Oxford University Press.

Leighley, Jan E., \& Jonathan Nagler. (2003) Unions and class bias in the U.S. electorate, 19642000. Paper presented at the Midwest Political Science Association, Chicago, April 3-5. 
Lindert, Peter H. (2004) Growing public social spending and economic growth since the eighteenth century. New York: Cambridge University Press.

McDonald, Michael D., and Ian Budge. 2005. Elections, Parties, Democracy. New York: Oxford University Press.

Mackie, Thomas, \& Richard Rose. (1991) The international almanac of electoral history. Washington D.C.: Congressional Quarterly.

Mackie, Thomas, and Richard Rose. (1997) A decade of election results: Updating the international almanac. Glasgow: Center for the Study of Public Policy, University of Strathclyde.

Mahler, Vincent. (2002) Exploring the subnational dimension of income inequality: An analysis of the relationship between inequality and electoral turnout in the developed countries. International Studies Quarterly 46 (1): 117-142.

Mahler, Vincent. (2008) Electoral turnout and income redistribution by the state: A crossnational analysis of the developed democracies. European Journal of Political Research 47 (2): 161-183.

Meltzer, Allan H., \& Scott F. Richard. (1981) A rational theory of the size of government. Journal of Political Economy 89 (5): 914-27.

Morton, Rebecca B. (1991) Groups in rational turnout models. American Journal of Political Science 35 (3): 758-76.

Mueller, Dennis C., \& Thomas Stratmann. (2003) The economic effects of democratic participation. Journal of Public Economics 87 (9-10): 2129-2155.

Perea, Eva Anduiza. (2002) Individual characteristics, institutional incentives and electoral abstention in Western Europe. European Journal of Political Research 41 (5): 643-673.

Piven, Frances Fox, and Richard A. Cloward. (1988) Why Americans don't vote. New York: Pantheon Books.

Pontusson, Jonas. (2005) Inequality and prosperity: Social Europe versus liberal America. Ithaca: Cornell University Press. 
Pontusson, Jonas, and David Rueda. (2010) The politics of inequality: Voter mobilization and left parties in advanced industrial states. Comparative Political Studies 43 (6): 675-705.

Powell, G. Bingham, Jr. (1980) Voting turnout in thirty democracies: Partisan, legal, and socioeconomic influences. In Electoral Participation: A Comparative Analysis, ed. Richard Rose. Beverly Hills, CA: Sage.

Przeworski, Adam, \& Michael Wallerstein. (1982) The structure of class conflict in democratic capitalist societies. American Political Science Review 76 (2): 215-238.

Radcliff, Benjamin. (1992) The welfare state, turnout, and the economy: A comparative analysis. American Political Science Review 86 (2): 444-456.

Rueda, David. (2005) Insider-outsider politics in industrialized democracies: The challenge to social democratic parties. American Political Science Review 99 (1): 61-74.

Rueda, F. David, \& Jonas Pontusson. (2000) Wage inequality and varieties of capitalism. World Politics 52 (3): 350-383.

Schattschneider, E.E. (1960) The semisovereign people: A realist's view of democracy in America. Hinsdale, IL: Dryden Press.

Scruggs, Lyle, \& James Allan. (2003) Trends in welfare state decommodification in eighteen advanced industrial democracies, 1972-2000. Paper prepared for presentation at the Annual Meeting of the American Political Science Association, Philadelphia, PA.

Sharp, Clifford. (1981) The economics of time. Oxford: Martin Robinson.

Solt, Frederick. (2004) Civics or structure? Revisiting the origins of democratic quality in the Italian regions. British Journal of Political Science 34 (1): 123-135.

Solt, Frederick. (2008) Economic inequality and democratic political engagement. American Journal of Political Science 52 (1): 48-60.

Varian, Hal R. (2003) Intermediate microeconomic theory: A modern approach. $6^{\text {th }}$ ed. New York: W.W. Norton.

Verba, Sidney, Kay L. Schlozman, \& Henry Brady. (1995) Voice and equality: Civic voluntarism in American politics. New York: Cambridge University Press. 
Wallerstein, Michael. 1999. "Wage-Setting Institutions and Pay Inequality in Advanced Industrial Societies." American Journal of Political Science 43 (3): 649-680. 


\section{Notes}

${ }^{1}$ There is, of course, a long-standing literature on the impact of inequality on revolutionary activity (Gurr 1970; Hibbs 1973).

${ }^{2}$ For studies at the subnational and supranational levels, see Boix (2003, 118-129), Solt (2004), Brady (2004), and Jesuit (2003).

${ }^{3}$ In contrast to data collected in the early 1970s (Verba, Kim, and Nie 1978; Barnes, Kaase, et al. 1979), more recent data show very distinct biases across different socio-economic groups across industrialized democracies (Norris 2002; Gallego 2007; Perea 2002; Caul 2005). Importantly, there is a consistent income skew in electoral participation, with individuals at the lower end of the income distribution less likely to participate (see also Mahler 2008).

${ }^{4}$ The effects of income on participation have been specified to be indirect, based on the idea that economic resources readily translate into resources (in particular, time) relevant for political action (Brady, Verba, and Schlozman 1995). Recently, Verba, Schlozman, and Brady (1995; see also Brady, Verba, and Schlozman 1995) have sought to specify more explicitly the role that resources (including income) play in shaping participation, hypothesizing that time, money, civic skills are most critical skills for participation. The theoretical prediction that income can be used to purchase time (the so-called "leisure effect") can be challenged by the argument that high wages raise the opportunity costs of free time (Sharp 1981).

${ }^{5}$ Electoral system type is an important control variable because of its potential effects on redistribution and party systems, as well as its direct effect on voters' decisions. While plurality systems are associated with lower turnout, less redistribution, and more inequality, proportional representation systems lead to social democratic preponderance, more redistribution, higher turnout, and less inequality (Iversen and Soskice 2006). A party that decides to ignore low income voters in a plurality system faces little political risk. Alternatively, PR systems facilitate the emergence of competition from third parties on either side of the median voter. In our case, this also means that PR can be a cause of a higher number of parties on the left. On top of facilitating a less disperse income distribution, and however short the lower income tale 
may be, this further reduces the temptation to abstain from mobilizing low income voters (Austen-Smith 2000).

${ }^{6}$ Empirically, this variable is closely related to district magnitude.

${ }^{7}$ This is consistent with research in political economy, which argues that inequality is shaped by income policies and policies of social protection, as more extensive levels of redistribution and income maintenance tend to lower levels of income inequality (see, e.g., Iversen and Soskice 2006; Kenworthy and Pontusson 2005; Rueda and Pontusson 2000; Beramendi and Cusack 2009) and the literature on representation, which shows that parties tend to keep their promises and that they are responsive to voters' wishes in the long run (McDonald and Budge 2005).

${ }^{8}$ Recent research by Mahler $(2002,2008)$ at the subnational and cross-national level argues that the relationship between turnout and redistribution is probably bidirectional.

${ }^{9}$ The p-value for economic coordination is .53 and for government ideology .14, with an r-squared for the estimation of .03 .

${ }^{10}$ The universe of cases is delimited by the availability of data. The following countries are included: Australia, Austria, Belgium, Canada, Denmark, Finland, France, Germany, Ireland, Italy, Netherlands, Norway, Sweden, Switzerland, United Kingdom, and the United States.

${ }^{11}$ The number of cases in our analyses of registered voters versus voting age population differs by two because turnout as a percentage of the voting age population is not available for Norway in 1997 and 2001.

${ }^{12}$ These results hold even when we control for what some consider outlier countries, such as the United States or Switzerland. "Dummying out" such countries slightly reduces the coefficient for income inequality, but these coefficients continue to pass conventional thresholds of statistical significance.

${ }^{13}$ Given our set of independent variables, multicollinearity could be a concern. However, Variance inflation factors (VIF) are well below conventional thresholds.

14 The countries are Australia, Canada, Denmark, Finland, France, Germany, Ireland, Netherlands, 
Norway, Spain, Sweden, Switzerland, the United Kingdom, and the United States. Austria was not part of this wave of the CSES surveys, and the survey for Belgium did not include a variable measuring income.

${ }^{15}$ For a discussion of the challenges inherent in using survey-based indicators of mobilization, see the discussion in Gerber and Green (2000). In particular, these concern the issue of measurement error.

${ }^{16}$ Technically, this means that we are estimating a three-way interaction. Generally, interactive effects can be estimated by stratifying the sample into relevant subsamples or, alternatively, specifying the behavioral differences within the overall model with interaction terms (Hanushek and Jackson 1977: 101). Because the interactions we specify are complex three-way interactions, the more straightforward split sample estimations are reported here.

${ }^{17}$ Because we rely on multi-level data, we use a method of analysis that allows for clustering of standard errors at the country-level, and because our data are survey data, we need to account for the nature of sample surveys collected in many countries. To deal with these complexities, we estimated a set of logistic regression models with respondents clustered by country and weighted by sampling weights, using an estimation technique developed for this purpose (the svy: logit command in STATA 10).

${ }^{18}$ For example, scholars have investigated the link between economic conditions and turnout at the level of countries (see e.g., Aguilar and Pacek 2000; Radcliff 1992). 
Figure 1. Mobilization of Low Income Voters Under Political Competition

$\mathrm{t}$

$\mathrm{P}_{\mathrm{L}}$

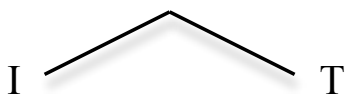

$\left(\mathrm{m}_{\mathrm{L}}=0\right)$

$\left(\mathrm{m}_{\mathrm{L}}>0\right)$

$\mathrm{t}+1$

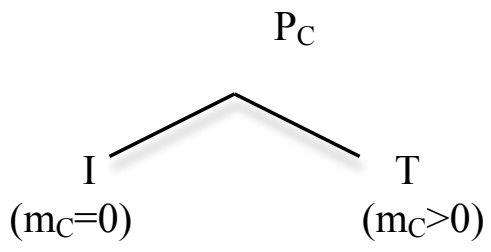


Table 1.

Instrumental Variable Estimates of Electoral Turnout in 14 Democracies, 1980-2002

\begin{tabular}{|c|c|c|}
\hline Turnout & $\begin{array}{c}\text { Voting Age } \\
\text { Population } \\
\text { Coefficient } \\
\text { (Standard Error) } \\
\end{array}$ & $\begin{array}{c}\text { Registered } \\
\text { Voters } \\
\text { Coefficient } \\
\text { (Standard Error) }\end{array}$ \\
\hline $\begin{array}{l}\text { Inequality below median } \\
\text { (instrumented) }\end{array}$ & $\begin{array}{l}-1.204 * * * \\
(.174)\end{array}$ & $\begin{array}{c}-1.202 * * * \\
(.129)\end{array}$ \\
\hline Eff. no. of left parties & $\begin{array}{c}-1.222 * * * \\
(.216)\end{array}$ & $\begin{array}{c}-1.255 * * * \\
(.174)\end{array}$ \\
\hline $\begin{array}{l}\text { Inequality * } \\
\text { Eff. no. of left parties }\end{array}$ & $\begin{array}{c}.637 * * * \\
(.112)\end{array}$ & $\begin{array}{l}.637 * * * \\
(.091)\end{array}$ \\
\hline Disproportionality & $\begin{array}{l}-.001 \\
(.002)\end{array}$ & $\begin{array}{l}-.001 \\
(.002)\end{array}$ \\
\hline Growth & $\begin{array}{l}-.002 \\
(.002)\end{array}$ & $\begin{array}{l}-.002 \\
(.002)\end{array}$ \\
\hline Vote share of left parties & $\begin{array}{l}-.024 \\
(.122)\end{array}$ & $\begin{array}{l}-.037 \\
(.119)\end{array}$ \\
\hline Competitiveness of election & $\begin{array}{l}.002 \\
(.002)\end{array}$ & $\begin{array}{l}.002 \\
(.001)\end{array}$ \\
\hline Holiday & $\begin{array}{c}-.090 * * * \\
(.019)\end{array}$ & $\begin{array}{c}-.108 * * * \\
(.017)\end{array}$ \\
\hline Automatic registration & $\begin{array}{l}.127 * * \\
(.030)\end{array}$ & $\begin{array}{l}.087 \\
(.043)\end{array}$ \\
\hline $\begin{array}{l}\text { Size of voting age } \\
\text { population }(\log )\end{array}$ & $\begin{array}{c}.097 * * * \\
(.017)\end{array}$ & $\begin{array}{c}.116^{* * *} \\
(.017)\end{array}$ \\
\hline Unicameralism & $\begin{array}{c}.170 * * * \\
(.035)\end{array}$ & $\begin{array}{c}.181 * * * \\
(.029)\end{array}$ \\
\hline Compulsory & $\begin{array}{c}.106^{* * *} \\
(.019)\end{array}$ & $\begin{array}{c}.128 * * * \\
(.010)\end{array}$ \\
\hline Constant & $\begin{array}{c}1.375 * * * \\
(.276)\end{array}$ & $\begin{array}{c}1.194 * * * \\
(.304)\end{array}$ \\
\hline Number of Observations & 94 & 96 \\
\hline Adj. R-squared & .88 & .87 \\
\hline
\end{tabular}

Notes: ***: $\mathrm{p}<.001 ; * *: \mathrm{p}<.01 ; *: \mathrm{p}<.05$. OLS and IV coefficient estimates; robust-cluster standard errors. Dependent variable: Electoral turnout in percent. The variable "Inequality below median" is the endogenous regressor. 
Table 2.

Income Inequality, Party Competition, and Party Contacting in 14 Democracies

\begin{tabular}{|c|c|c|c|c|}
\hline & \multicolumn{2}{|c|}{ Below Median Income } & \multicolumn{2}{|c|}{ Median Income and Above } \\
\hline & Model 1 & Model 2 & Model 2 & Model 4 \\
\hline Inequality below median & $\begin{array}{l}.160 \\
(.396)\end{array}$ & $\begin{array}{l}-.414 \\
(.723)\end{array}$ & $\begin{array}{l}2.755 * * * \\
(.340)\end{array}$ & $\begin{array}{l}3.815 * * * \\
(.493)\end{array}$ \\
\hline Eff. No. of Left Parties & $\begin{array}{c}-2.243 * * * \\
(.461)\end{array}$ & $\begin{array}{c}-3.881^{* * *} \\
(.846)\end{array}$ & $\begin{array}{l}.307 \\
(.414)\end{array}$ & $\begin{array}{l}1.126^{*} \\
(.553)\end{array}$ \\
\hline Inequality * Left Parties & $\begin{array}{c}1.243 * * * \\
(.219)\end{array}$ & $\begin{array}{c}1.652 * * * \\
(.402)\end{array}$ & $\begin{array}{l}.056 \\
(.192)\end{array}$ & $\begin{array}{l}-.637 * \\
(.270)\end{array}$ \\
\hline Micro-Level Variables & & & & \\
\hline Age & $\begin{array}{l}-.000 \\
(.002)\end{array}$ & $\begin{array}{l}.011 \\
(.007)\end{array}$ & $\begin{array}{l}.004 \\
(.006)\end{array}$ & $\begin{array}{l}.004 \\
(.006)\end{array}$ \\
\hline Gender & $\begin{array}{l}-.093 \\
(.060)\end{array}$ & $\begin{array}{l}-.422 \\
(.225)\end{array}$ & $\begin{array}{l}-.149 \\
(.157)\end{array}$ & $\begin{array}{l}-.149 \\
(.157)\end{array}$ \\
\hline Education & $\begin{array}{c}.117 * * * \\
(.018)\end{array}$ & $\begin{array}{l}.192 * \\
(.086)\end{array}$ & $\begin{array}{l}.014 \\
(.050)\end{array}$ & $\begin{array}{l}.014 \\
(.050)\end{array}$ \\
\hline Union membership & $\begin{array}{l}.394 * * * \\
(.069)\end{array}$ & $\begin{array}{l}.219 \\
(.241)\end{array}$ & $\begin{array}{l}.277 \\
(.166)\end{array}$ & $\begin{array}{l}.277 \\
(.166)\end{array}$ \\
\hline $\begin{array}{l}\text { Left-right ideology } \\
\text { (high = right) }\end{array}$ & $\begin{array}{l}-.009 \\
(.013)\end{array}$ & $\begin{array}{l}.068 \\
(.050)\end{array}$ & $\begin{array}{l}.006 \\
(.040)\end{array}$ & $\begin{array}{l}.006 \\
(.040)\end{array}$ \\
\hline $\begin{array}{l}\text { Married } \\
(1=\text { yes })\end{array}$ & $\begin{array}{l}-.079 \\
(.061)\end{array}$ & $\begin{array}{l}.492 * \\
(.223)\end{array}$ & $\begin{array}{l}.192 \\
(.178)\end{array}$ & $\begin{array}{l}.192 \\
(.178)\end{array}$ \\
\hline Macro-Level Variables & & & & \\
\hline Disproportionality & $\begin{array}{l}.007 \\
(.006)\end{array}$ & $\begin{array}{c}-.033 * * \\
(.012)\end{array}$ & $\begin{array}{l}-.002 \\
(.006)\end{array}$ & $\begin{array}{l}-.009 \\
(.009)\end{array}$ \\
\hline Holiday voting & -- & $\begin{array}{c}-.919 * * * \\
(.161)\end{array}$ & -- & $\begin{array}{c}-.745 * * * \\
(.097)\end{array}$ \\
\hline Automatic registration & -- & $\begin{array}{l}.299 * \\
(.145)\end{array}$ & -- & $\begin{array}{l}-.196^{*} \\
(.091)\end{array}$ \\
\hline Voting age population (log) & -- & $\begin{array}{l}-.064 \\
(.075)\end{array}$ & -- & $\begin{array}{c}-.318 * * * \\
(.057)\end{array}$ \\
\hline Unicameralism & -- & $\begin{array}{l}.249 \\
(.165)\end{array}$ & -- & $\begin{array}{l}-.008 \\
(.122)\end{array}$ \\
\hline Compulsory & -- & $\begin{array}{l}.433 * * * \\
(.063)\end{array}$ & -- & $\begin{array}{l}.351 * * * \\
(.048)\end{array}$ \\
\hline Constant & $\begin{array}{c}-2.460 * * \\
(.832)\end{array}$ & $\begin{array}{c}.321 \\
(1.764)\end{array}$ & $\begin{array}{l}-7.495 * * * \\
(.722)\end{array}$ & $\begin{array}{c}-3.064 * * \\
(1.036)\end{array}$ \\
\hline $\begin{array}{l}\text { Micro-N } \\
\text { Macro-N }\end{array}$ & $\begin{array}{c}7304 \\
14\end{array}$ & $\begin{array}{c}7304 \\
14\end{array}$ & $\begin{array}{c}11239 \\
14\end{array}$ & $\begin{array}{c}11239 \\
14\end{array}$ \\
\hline
\end{tabular}

Notes: $* * *: \mathrm{p}<.001 ; * *: \mathrm{p}<.01 ; *: \mathrm{p}<.05$. Logistic regression estimates (respondents clustered by country); standard errors in parentheses. Dependent variable: party contact during election campaign $(1=\mathrm{yes} ; 0=\mathrm{no})$. 
Figure 2. Mobilization Gaps Between High and Low Income Voters

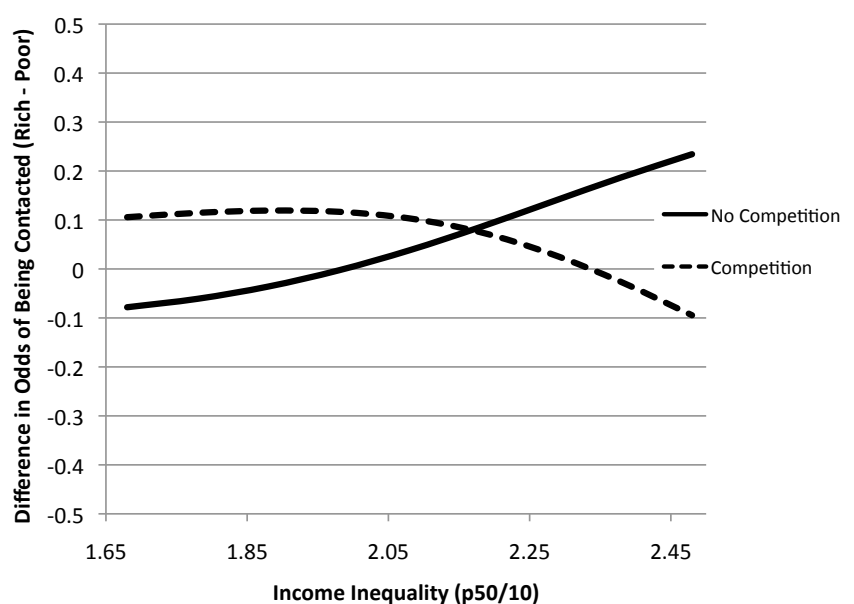




\section{Author Bios}

Christopher J. Anderson is Professor of Government at Cornell University.

Pablo Beramendi is a professor at the Department of Politics and International Relations at Oxford University and a Fellow of University College.

\section{Acknowledgments}

Previous versions of the paper were presented at the Maxwell School of Syracuse University, the Center for the Study of Democracy, University of California, Irvine, the Institute for the Social Sciences, Cornell University, the Juan March Institute, Madrid, and the annual meetings of the American Political Science Association and the Midwest Political Science Association. We are grateful to the audiences for their helpful discussions and in particular Michael D. McDonald, Jonas Pontusson, Dulce Manzano, and Francesc Amat for their very helpful comments on previous versions of this paper. Thanks also to Matt Cleary and students in his Comparative Political Analysis seminar at Syracuse University for providing helpful suggestions. We also thank Mikki Caul Kittilson, Michael D. McDonald, and Lyle Scruggs for help with obtaining some of the macro-level data. The survey data are available as ICPSR Studies No. 2683 and 3808. The original collector of the data, ICPSR, and the relevant funding agency bear no responsibility for uses of this collection or for interpretations or inferences based upon such uses. 